\title{
ДИСКУССИЯ ПРАВОСЛАВНОГО ДУХОВЕНСТВА ПО ПОВОДУ ЦЕРКОВНО- СВЕЧНОЙ ОПЕРАЦИИ И СОЗДАНИЯ ЕПАРХИАЛЬНЫХ СВЕЧНЫХ ЗАВОДОВ В МЕСТНОЙ ПЕРИОДИЧЕСКОЙ ПЕЧАТИ (ПО МАТЕРИАЛАМ «ВОРОНЕЖСКИХ ЕПАРХИАЛЬНЫХ ВЕДОМОСТЕЙ»)
}

\section{THE DISCUSSION OF THE ORTHODOX CLERGY ABOUT CHURCH-CANDLE OPERATION AND OPENING EPARCHY CANDLE FACTORIES IN LOCAL PERIODICALS (ON THE MATERIALS OF «VORONEZH EPARHIAL'NYE VEDOMOSTI»)}

\author{
Д.В. Наумов \\ D.V. Naumov \\ Белгородский государственный национальный исследовательский университет, \\ Россия, 308015, г. Белгород, ул. Победы, 85 \\ Belgorod State University, \\ 85 Pobeda St, Belgorod, 308015, Russia \\ E-mail: naumov_d@bsu.edu.ru
}

\begin{abstract}
Аннотация
В статье рассматривается полемика православного духовенства Воронежской епархии по вопросу создания епархиальных свечных заводов и способов получения прибыли от продажи церковных свечей. Во второй половине XIX века православное духовенство было вынуждено самостоятельно изыскивать способы улучшения собственного материального положения. Одним из таких способов могли стать доходы, получаемые от продажи церковных свечей. Являясь неизменным атрибутом христианского богослужения, церковная свеча играла и важную экономическую роль. Тем не менее до конца XIX века доходы от продажи свечей получали частные фабриканты, которые часто производили свечи ненадлежащего качества, добавляя в них различные примеси. Однако создание собственных епархиальных заводов было трудным и затратным делом для духовенства. В местной периодической печати существовали различные мнения и точки зрения по данному вопросу. Обсуждение проектов создания свечного завода в Воронежской епархии затянулось на несколько десятилетий.
\end{abstract}

\begin{abstract}
The article deals with discussion of the orthodox clergy of Voronezh eparchy about the problem opening eparchy candle factories and ways to get profit from church candle's sale. In the second half of XIX century orthodox clergy were forced to find ways to make its financial situation better. One of these ways could become profit received from church candle's sale. Church candle was the immutable attribute of Christian worship. Church candle played an important economic role. Nonetheless, until the end of XIX century private merchants made profits from candles' sale. Private merchants often made bad quality church candles, adding some admixtures. It made bad influence on candles and then on the worship. Opening own candle's factories was difficult and costly business for clergy. In local periodicals there were different opinions and viewpoints about this problem. The discussion of projects about opening candle's factory in Voronezh eparchy was slow down a few decades. It was serious and difficult problem for the clergy.
\end{abstract}

Ключевые слова: православное духовенство, церковно-свечная операция, материальное положение духовенства, церковные реформы, периодическая печать.

Keywords: orthodox clergy, church-candle operation, financial situation of clergy, the church's reforms, periodicals. 
Материальное обеспечение православного духовенства было одним из главных вопросов церковных реформ, проводившихся при Александре II. Однако к 1870-м годам стало очевидно, что правительство не сможет обеспечить духовенство в полной мере. В этих непростых условиях епархиальное духовенство пыталось изыскать возможности для улучшения материального состояния приходов. Одним из таких способов потенциально могли стать средства, получаемые от церковно-свечной операции (в указанный период так называли продажу свечей и восковой продукции).

В современной историографии проблема материального обеспечения православного духовенства неоднократно становилась предметом научного изучения. Можно выделить работы Т.Г. Леонтьевой [Леонтьева, 2002], Б.А. Ершова [Ершов, 2012], Б.Н. Миронова [Миронов, 2015], А.В. Всеволодова [Всеволодов, 2017], Д.А. Беговатова [Беговатов, 2017], Ю.И. Белоноговой [Белоногова, 2017], С.А. Иконникова [Иконников, 2015]. При этом изучение церковно-свечной операции и процесса создания епархиальных свечных заводов практически не велось. Отдельного внимания в этом отношении заслуживает статья С.А. Иконникова [Иконников, 2018].

Свечи являлись непременным атрибутом христианского богослужения, поэтому церквям они требовалось в большом количестве. Епархиальные свечные заводы стали появляться в России лишь в конце XIX века. До этого времени свечи производились на частных заводах, следовательно, большая часть прибыли шла в руки частных фабрикантов, в то время как данные средства можно было направить на улучшение материального обеспечения православного духовенства. К тому же далеко не все производители добросовестно подходили к изготовлению восковых свечей, ради удешевления добавляя в их состав различные примеси (например, парафин). Такие свечи коптили и издавали неприятный запах.

Петр I, Елизавета Петровна, Александр I принимали указы, целью которых была регламентация производства и торговли восковыми свечами, а также пресечение наживы на этом со стороны фабрикантов [Иконников, 2018]. Усилия были направлены на запрещение незаконной торговли свечами (розничная торговля допускалась только при церквях или в церковных лавках), ужесточение наказания за подделку свечей и т. д. Однако все предпринимаемые в разные годы меры не сумели достичь главной цели - незаконная торговля свечами продолжалась, а Церковь по-прежнему лишалась значительной статьи доходов. А доходы были довольно солидными. Так, например, по данным на 1879 г. в Воронежской губернии производством свечей занимались 8 фабрикантов (а также Митрофановский монастырь), общий объем производства составлял 9850 пудов на сумму 210300 рублей [Указатель фабрик и заводов, 1881, с. 228]. Крестьяне стремились приобретать свечи по более низким ценам, несмотря на то, что такие свечи были гораздо хуже по качеству. Разница в цене могла составлять от 2 до 4 рублей с пуда [О продаже восковых свечей, 1876, с. 815].

Вопрос о церковно-свечной операции был очень важным для епархиального духовенства. Начало процессу обсуждения положил священник Дмитрий Склобовский. Публикуя материалы к предстоящему епархиальному съезду воронежского духовенства (съезд проходил 10-12 января 1878 г.), он выделил 2 вопроса «громадной важности»: вопрос о епархиальном свечном заводе и вопрос об эмеритуре [Склобовский, 1877, с. 368]. Он обратил внимание на необходимость строительства собственного свечного завода, который позволил бы епархии извлекать большую прибыль. Строительство епархиального свечного завода требовало значительных затрат: 400000 рублей для мощностей завода, позволявших производить в год 15000 пудов свечей (ежегодная прибыль составила бы 30000 рублей) и 150000 рублей на завод, который смог бы производить 4000 пудов (ожидаемая прибыль составила бы 4800 рублей в год) [Там же, с. 369]. Расчеты производились комиссией по устройству епархиального свечного завода для Петербургского духовенства. Помимо экономических выгод епархиальный свечной завод позволил бы поддерживать качество восковых свечей, избавить их от всяких «гадких» примесей, введенных «безбожным кулачеством» [Там же]. Церкви испытывали серьезную конкуренцию со стороны «базарных и яр- 
морочных рынков», которые «парализуют церковную продажу свечей». При правильном подходе к делу епархиальный свечной завод мог бы давать епархии хорошие доходы.

Священник Д. Склобовский предлагал духовенству Воронежской епархии еще до самого съезда решить несколько основных вопросов. Главным из них был вопрос: решится ли епархиальное духовенство на строительство епархиального свечного завода либо же доверит поставки свечей в церкви местным фабрикантам. В первом случае необходимо было первоначально выбрать место для будущего завода. Если же духовенство решило бы доверить поставки фабрикантам, то Д. Склобовский предлагал выбрать в качестве поставщиков купцов Бухонова и Стрельцова. Д. Склобовский мотивировал это тем, что они имеют репутацию людей честных и добросовестных, которые не позволяли на своих заводах производить продукцию ненадлежащего качества. Д. Склобовский призывал духовенство епархии взяться за решение этих вопросов еще до съезда. В противном случае съезд не смог бы прийти к конкретному решению, ему бы осталось только «разглагольствовать о свечах и свечных заводах, пробавляться одними догадками и предположениями, да еще, пожалуй, составлять бесконечные экспедиции или комиссии» [Там же, с. 374]. Решение вопроса о свечном заводе могло затянуться на долгие годы, в течение которых духовенство Воронежской епархии будет «витать в области идей и принципов» [Там же].

Инициатива Д. Склобовского вызвала обсуждение в «Воронежских епархиальных ведомостях». Священник Н. Сильченко высказал целый ряд своих соображений. Так, он скептически отнесся к сумме, которая планировалась на создание завода. По его мнению, цифры, рассчитанные Петербургской комиссией, как минимум явно завышены для Воронежской епархии. Н. Сильченко аргументировал это тем, что сумма в 400000 рублей является неподъемной, поскольку у духовенства епархии «никогда, кажется, не может быть в распоряжении такой громадной суммы» [Сильченко, 1877, с. 520]. Он полагал, что суммы в 75 тыс. рублей будет достаточно. Препятствием к этому могло стать то обстоятельство, что, во-первых, епархиальное духовенство не имело в наличии такой суммы (Н. Сильченко называется сумма «свободных» денег не более 4500 рублей), а во-вторых, строительство завода потребовало бы временных затрат, в течение которых духовенство лишалось бы потенциальной прибыли. В этих условиях он предлагал разрешить производство и продажу церковных свечей выбранному Съездом купцу, который согласился бы на определенных условиях продавать их, а часть полученной прибыли отдавать в пользу духовенства. По мнению автора проекта, в год епархиальным церквям требуется порядка 10 тыс. пудов свечей, при отчислении 2-3 рубля с пуда в пользу епархии в год получилась бы сумма в 20-30 тыс. рублей. За 3 года накопилась бы сумма, достаточная для постройки завода, к чему и можно было приступить. Н. Сильченко настаивал на этом варианте, поскольку считал его более осторожным и рассудительным. Во избежание обмана и нечестности со стороны фабриканта, он предлагал составить специальную комиссию, составленную преимущественно из городских священников. Эта комиссия получила бы право контроля над финансовой стороной вопроса, а в случае выявления финансовых нарушений могла бы без дополнительных согласований расторгнуть договор аренды и выбрать другого купца.

Съезд духовенства Воронежской епархии, состоявшийся 10 января 1878 г., действительно создал комиссию по церковно-свечной операции. Вызвано это было отсутствием свободных наличных денежных средств на строительство свечного завода. В этих обстоятельствах съездом было принято решение «отсрочить на известное время устройство Епархиального свечного завода» и в течение некоторого периода времени собрать необходимые средства [Журнал заседания съезда депутатов, 1878, с. 31]. По сути, было создано две комиссии: первая должна была заняться сбором необходимой подготовительной информации для строительства будущего свечного завода; вторая (получила название центральной) занималась непосредственно закупкой и распространением свечей. В каждом благочинническом округе епархии был священник, который был уполномочен покупать свечи от комиссии, взамен высылая денежные средства на имя казначея в центральное управление. Программа действий данной комиссии была напечатана в «Воронежских епархиальных ведомо- 
стях» [Программа действий центральной комиссии, 1878]. Все церкви епархии были обязаны закупать свечи только от данной комиссии, в противном случае полагался штраф: за первое нарушение - 10 рублей с каждого пуда незаконно приобретенных свечей, за повторное нарушение - 20 рублей, при нарушении в третий раз - 30 рублей. Покупка свечей в других местах запрещалась даже в случае отсутствия в церкви свечей (это могло произойти по причине несвоевременной доставки, проволочек, связанных с «бумажными» делами, и т. д.). В таком случае предписывалось занимать свечи из тех соседних церквей, где имелся запас, но «ни в коем случае не покупать свечи помимо центральной комиссии» [Программа действий центральной комиссии, 1878, с. 40]. Кроме того, комиссия обязывалась покупать свечи наилучшего качества, не допуская тех, что «производят копоть и угар в церкви». Комиссия и церкви епархии были обязаны вести строгий учет и контроль деятельности как финансовой, так и хозяйственной стороны вопроса.

Однако с самого начала своей деятельности комиссия столкнулась с трудностями. Эти трудности и общее положение дел подробно описал в своей статье член комиссии священник Иоанн Сахаров [Сахаров, 1878]. Как можно выяснить из этой публикации, на самом съезде не было единодушия. Часть представителей воронежского духовенства не поддержала идею организации свечного завода, выступив против. В таких условиях комиссии пришлось очень непросто, если бы «Его Высокопреосвященство не отнесся к ней - комиссии - и к интересам всего духовенства с полнейшим отеческим сочувствием» [Там же, с. 220]. Комиссия выполнила главное поручение - ей были закуплены свечи для продажи во всех благочиниях епархии. Комиссия отмечала тот факт, что она не имеет полномочий для преследования незаконной торговли восковыми свечами, поскольку это дело всего епархиального духовенства, а кроме того, «епархия велика и видеть, что делается в разных ее закоулках, разумеется, нет никакой возможности» [Там же, с. 221]. Кроме того, И. Сахаров отмечал, что церковные старосты могли помешать спокойному течению дела. Они могли закупать свечи у других производителей, несмотря на то что предписывалось покупать свечи только у комиссионера [Сахаров, 1878, с. 222]. В своей статье И. Сахаров призывал все епархиальное духовенство принять деятельное участие в церковно-свечной операции во избежание превращения данной комиссии в «разряд всех вообще пресловутых комиссий и подкомиссий», несмотря на «сердечную готовность своих членов послужить епархии» [Там же, с. 224].

Другим членом комиссии, который решил высказать свое видение проблемы в епархиальной периодике, был священник Аристарх Аристов (вышел из состава комиссии в мае 1878 г. по «домашним и служебным обязанностям»). Главной трудностью он назвал отсутствие в распоряжении комиссии денег - не было дано «ни одного гроша денег для предполагаемых и указанных комиссии операций» [Аристов, 1878, с. 469]. По этой причине единственным поставщиком, с которым удалось договориться, стал Митрофанов монастырь. Все остальные отказывались, поскольку «ни одному свечному заводчику комиссия не могла дать задатка за купленные свечи» [Там же]. При этом, несмотря на все трудности, дело удалось наладить в довольно короткие сроки. Более того, по утверждению А. Аристова, в течение 4-5 месяцев комиссия могла рассчитывать на прибыль до 10000 рублей.

Создавало препятствие и епархиальное духовенство. А. Аристов отмечал, что данные о количестве необходимых свечей в некоторых случаях вызывали сомнения, 17 благочиний вообще не прислали запросы на поставку свечей, а в 19 не избрали комиссионеров [Там же, c. 473]. Помимо недовольства некоторых представителей духовенства в адрес комиссии, в т. ч. упреков в ненадлежащем расходовании средств, А. Аристов упоминает письмо от некоего лица «не низко поставленного в духовенстве» в Воронежскую духовную консисторию. В письме это «лицо» выступило против закупки свечей у комиссии, сообщив, что свечи в необходимо количестве уже были закуплены на стороне.

Статьи с критикой принятых решений епархиального съезда и действий комиссии не заставили себя ждать. Уже в следующем номере (№ 13 за 1878 г.) выступил священник слободы Новотроицкой Валуйского уезда Иаков Васильев. В своей статье он подверг до- 
вольно резкой критике изначально существовавшие финансовые планы по получению прибыли. В частности, он заявил о том, что планировавшая прибыль в 8-9 рублей с пуда восковых свечей не соответствует реально существующей картине. Вспомнив знаменитое устойчивое словосочетание «игра не стоит свеч», он перефразировал его - «свечи не стоят столь неумной игры» [Васильев, 1878, с. 503]. Он писал: «смотря по тем ошибкам недодуманной мысли, которые сделаны - одна съездом, а другая, и гораздо большая, - одной комиссией, нам не останется и по 2 рубля» с каждого проданного пуда церковных свечей [Там же]. Как утверждал И. Васильев, комиссия покупала свечи не по тем ценам, которые были изначально запланированы; во-вторых, практика выбора в каждом благочинии особого комиссионера, а также то, что комиссия «своим неуместным, чтобы не сказать более, распоряжением» о ежемесячной высылке денег от продажи резко увеличила расходы церковных старост. Необходимость каждый месяц отправлять вырученные средства вынуждала их совершать минимум по 12 поездок на почту в год, что было связано с рядом трудностей и издержек. Совместно с расходами церковных старост И. Васильев называл сумму расходов на дорожные и почтовые издержки в 182 рубля. По его мнению, если комиссия не учитывает эти расходы, то она стоит «на фальшивой дороге». А церкви - это тот «уже почти иссохший источник, из которого только пока и можно что-либо почерпнуть» [Там же, с. 505]. К тому же ситуацию затрудняла нерегулярная доставка свечей комиссией и невозможность требовать комиссионеру штрафных выплат от старост церквей за просроченные платежи. Поэтому священник И. Васильев настаивает на необходимости «выбросить лишнюю спицу из многосложной и без того свечной колесницы - комиссионера» или хотя бы заменить ежемесячные платежи полугодичными [Там же, с. 506].

Дмитрий Склобовский в ответ на заметку священника А. Аристова выпустил свою статью. В ней он посетовал на нежелание Воронежского духовенства принимать участие в делах на благо всей епархии. Он охарактеризовал это так: «ересь субъективизма положительно заедает современное общество и в среде Воронежского градского духовенства по справедливости считается довольно распространенною», а ее последователи теряют «способность объективно относиться к любому общественному делу или вопросу» [Склобовский, 1878, с. 650]. Раскритиковал Д. Склобовский и ряд утверждений А. Аристова. В частности, он назвал финансовые трудности, на которые ссылался А. Аристов, препятствием «если не мнимым, то легко устранимым». Д. Склобовский указывал на тот факт, что комиссия выбрала Митрофанов монастырь в качестве поставщика свечей не потому, что не имела средств договориться с частными фабрикантами (хотя, по утверждению Д. Склобовского, комиссия обращалась ко всем продавцам Воронежской епархии), а потому, что монастырь сумел предложить наиболее выгодную цену. Д. Склобовский ссылался на разговор с одним из воронежских купцов, который предлагал духовенству епархии не взваливать на себя такое трудное дело, как строительство собственного завода, а остановиться на получении процента от прибыли проданных свечей, используя мощности какого-либо существующего свечного завода. Церковная свеча - это «самый важный ценз, единственный источник прямого и совершенно правильного обеспечения церквей и потом духовенства, но источник далеко еще не разработанный, <..> почти слегка только затронутый, только в будущем ожидающий правильной реализации» [Там же, с. 661]. К сожалению, как писал Д. Склобовский, духовенство Воронежской епархии «на половину отнеслось ко всему этому с явным пренебрежением и наперекор чему угодно, в конечное истребление всех благих чаяний, обнаруживает непостижимую косность в таком деле, в котором самым живейшим образом требуется и призывается вся его энергия» [Там же, с. 663].

В заметке «По вопросу о церковно-свечной операции» [По вопросу о церковносвечной операции, 1878] неназванный автор предлагает сконцентрировать внимание на решении наиболее важных вопросов. Главный из них - это организовать производство церковных свечей путем создания собственного свечного завода. По мнению автора, это положение, как аксиома, «не должно подлежать ни спору, ни сомнениям» [Там же, с. 925]. Поэтому необходимо не допускать покупку свечей незаконным образом потому, что в некоторых церквях 
свободная покупка свечей «широко откроет двери бессовестному барышничеству» [Там же, c. 928]. Если же создание собственного свечного завода встретит непреодолимые трудности, то в таком случае необходимо объединить усилия с Митрофановским монастырским заводом. Монастырское правление на деле доказало, что «с ним можно вести всякое капитальнейшее дело без всяких бумажных актов» [Там же, с. 930].

Священник А. Понятовский также подверг критике деятельность центральной комиссии по церковно-свечной операции. А. Понятовский выразил недовольство теми средствами, которыми она достигается. Комиссией не были учтены существовавшие правила покупки церквями свечей, разница в их количестве и др. Поэтому эти средства и «вызвали такие неотрадные последствия» [Понятовский, 1879, с. 58]. Как и И. Васильев, он отмечал необходимость затрат на дорогу, связанную с покупкой свечей и их оплатой. Более того, жесткая периодичность закупок нарушала привычный ход церковной деятельности. Не только в разных церквях, но и в разное время года продажа свечей осуществлялась с разной скоростью.

Наибольшую критику со стороны А. Понятовского вызывали штрафы. С учреждением новых правил церковно-свечной операции церковный староста был обязан в установленные сроки доставить требуемую сумму для закупки в полном объеме. Это ставило церковных старост в очень непростую ситуацию: в случае неявки будет выписан штраф, поскольку комиссия «будет думать, что свечи куплены на стороне» [Там же, с. 59].

Другим объектом критики А. Понятовского была цена на свечи, установленная комиссией. Она была завышена - «прежде свечи покупались по 18 р. за пуд, а теперь положили 24 р.». Более высокое качество свечи, купленной у комиссии, не оправдывало такую высокую цену в глазах церковных старост и крестьян. А. Понятовский писал о том, что, убеждая крестьян покупать свечи только в церкви, действовал «против собственных убеждений». Крестьян аргументация священника не убеждала - «никакие разъяснения и убеждения не в силах сбить мужика с избранной им точки опоры» [Там же, 63]. Прекратить это силами одного священника было нельзя. Рассчитывать на помощь церковного старосты не приходилось, поскольку тот в большинстве случаев сторонник «интересов мира, нежели церкви».

Все сложившуюся ситуацию А. Понятовский сравнил с ростовщичеством, которое не щадит никого и ничего, «копящее капитал законными и незаконными путями» [Понятовский, 1879, с. 62]. Им были предложены следующие меры по нормализации происходящего - отмена штрафов и отмена жестких сроков по закупкам свечей. В противном же случае комиссия оттолкнет от себя и тех, «кто сочувствовал ей во имя сочувствия общеепархиальным интересам, а через то выйдет и еще трагикомический результат» [Там же, с. 68].

Отклик на данную статью не заставил себя ждать. В ответ вышла публикация священника И. Сахарова, в которой тот подробно разобрал работу А. Понятовского и выдвинул свои контраргументы [Сахаров, 1879]. Для начала И. Сахаров отметил позитивную сторону общественного обсуждения таких сложных вопросов, каким является церковносвечная операция. Все заметки, «возражения, сомнения и недоумения, выраженные публично путем печати, и на принципах строгой правды и теплого сочувствия составят дорогой вклад» в общее дело, поскольку в них освещались те проблемы, с которыми сталкивались представители духовенства в ходе реализации задуманного. Однако работу А. Понятовского И. Сахаров отказался причислять к этой категории, поскольку посчитал ее тенденциозной. И. Сахаров упрекнул священника А. Понятовского в чрезмерном рвении, в результате которого и страдали отношения с прихожанами, в то время как указы комиссии не вынуждали действовать строгими и радикальными методами. И как бы ни были сильны в обществе негативные настроения в адрес комиссии, причина недовольства церковных старост и некоторых священников кроется совсем в другом. И. Сахаров видел ее в том, что церковные старосты опасались потерять свое влияние, поскольку «духовенство врывается в такую область, где они (иерковные старосты - прим. Д.Н.) были до сего времени бесконтрольными хозяевами, и что их независимой покупке и продаже церковных свечей 
приходит конец» [Там же, с. 382]. Недовольство же некоторых священников объяснялось опасениями с их стороны потерять часть церковных доходов, в результате чего церковь становилась бы беднее. Кроме того, в некоторых случаях имел место сговор священника и церковного старосты с тем, что закупать свечи в обход установленных правил.

И. Сахаров указывал на данные, полученные им из некоего достоверного источника, согласно которым доходы от продажи свечей центральной комиссией в 1878 - первой половине 1879 г. оказались куда ниже ожидаемых, а количество отправленных свечей было гораздо ниже требуемого - «они едва ли покрывают собой пятую часть действительного по епархии расхода» [Там же, с. 383]. И. Сахаров настаивал на строительстве собственного епархиального свечного завода. Для успешной борьбы «со свечными торговцами, эксплуатирующими наши церкви и народ», необходима честная конкуренция. В противном случае «мы ничем не осилим этих торговцев», - писал И. Сахаров.

Не только А. Понятовский был противником того, как проводилась церковносвечная операция, звучали голоса других противников и критиков. Одним из таких был священник Скрябин (инициалы в статье не были указаны). Данный автор вступил в полемику с Д. Склобовским. Так, он сообщал о том, что поставляемые комиссией свечи «по своему качеству, объему и цвету оказались ниже посредственности» [Скрябин, 1879, c. 645]. Свечи, поставляемые комиссией, оказались тоньше и меньше тех, что прежде покупались у торговцев. К тому же комиссия не могла обеспечить ассортимент поставляемой продукции - наиболее продаваемые маленькие свечи не поставлялись вовсе. Это вызывало неудовольствие и негодование со стороны прихожан в адрес духовенства, «затеявшего новые порядки». В результате свечи прихожанами покупались в больших объемах у торговцев, а не в церкви.

Упрекал священник Скрябин комиссию и в нерегулярности поставок. Поставляемые свечи приходили с большим опозданием. Так, например, в 1879 г. свечи были отправлены не в начале года, как требовались, а лишь в марте. Священник задавал вопрос всему епархиальному духовенству: «Что делать тем несчастным церквям, которые более чем своевременно представили о. комиссионеру требование о нужном количестве свечей на первую половину текущего года, не получали оных из комиссии до конца марта месяца, т. е. на такие месяцы, в которые <...> бывает самый большой расход свечей» [Скрябин, 1879 , c. 646].

Скрябин предлагал разрешить свободную закупку свечей церквями с тем условием, что они отчисляют 3-4 рубля в пользу епархии с каждого проданного пуда. Собранные деньги предлагалось отсылать в Попечительство о бедных духовного звания, которое обязывалось хранить в Воронежском городском банке либо другом финансовом учреждении для «хранения и приращения процентами».

Наиболее активный участник обсуждения в «Воронежских епархиальных ведомостях» Д. Склобовский в 1880 г. выступил с очередной статьей. Название статьи говорит о многом: латинское выражение idem per idem можно перевести как «замкнутый круг». Комиссию по церковно-свечной операции Д. Склобовский назвал «фантасмагорией», которой «на делах в Епархии нигде почти уже и незаметно, которой и самое существование можно только подозревать по некоторым самым неясным признакам» [Склобовский, 1880, c. 424]. В епархии, по словам Д. Склобовского, царит «гробовое молчание» по вопросу о церковно-свечной операции, несмотря на количество написанных статей. «Правительство отлично знает, что духовенство по-прежнему остается все в том же нищенском положении, значит, на тощих карманах этого сословия никаких расчетов основывать невозможно; знает оно также и о том, что и церковные карманы вследствие непомерных взносов и налогов на них, с каждым годом более и более умножающихся и возрастающих, до самого дна уже исчерпаны» [Там же, с. 427]. Значит, только получение доходов от церковносвечной операции могло дать духовенству дополнительные средства. Однако за прошедшие годы с момента начала обсуждения никаких серьезных подвижек не произошло, а комиссия не только не поспособствовала этому, а наоборот только «опустила руки». 
Д. Склобовский критиковал комиссию за отсутствие инициативы, деятельного подхода, непоследовательности и многое другое. Д. Склобовский призывал активнее бороться с незаконной торговлей, а также вести строгую смету необходимого количества свечей для каждой церкви в епархии.

Вопрос о церковно-свечной операции выявил разногласия в среде воронежского духовенства. «Воронежские епархиальные ведомости» стали площадкой для обсуждения различных точек зрения, обсуждений и споров. Точка зрения того или иного автора зависела от множества факторов, в т. ч. и от того, в каком приходе служил конкретный клирик. Представители городского и сельского духовенства по-разному видели способы извлечения прибыли от продажи церковных свечей. Часть духовенства не желала каких-либо изменений, их устраивало существовавшее положение вещей, и они составляли оппозицию центральной комиссии по церковно-свечной операции. Несмотря на столь длительные и острые дискуссии, епархиальный свечной завод был всё-таки открыт в 1881 г. в Воронеже и стал играть важную роль в материальном обеспечении духовенства. С.А. Иконников приводит следующие данные: в 1913 г. чистая свечная прибыль в Воронежской епархии составила 452238 рублей 39 копеек (44 \% всех церковных доходов) [Иконников, 2018]. Получаемые доходы от продажи свечей позволили местному духовенству улучшить финансирование духовных учебных заведений, приходских храмов и т. д.

\section{Список литературы}

1. Аристов А., свящ. 1878. Заметка по свечной операции. Прибавления к Воронежским епархиальным ведомостям, 12: 469-474.

2. Беговатов Д.А. 2017. Городское православное духовенство Тверской епархии в первой половине XIX века: профессиональная деятельность и повседневная жизнь. Тверь, СФК-офис, 312.

3. Белоногова Ю.И. 2017. Материальное обеспечение церквей в XIX - начале XX в. на примере храмов Волоколамского благочиния Московской епархии. Вестник Православного СвятоТихоновского гуманитарного университета. Сер. 2: История. История Русской Православной Церкви, 79: 46-54.

4. Васильев И., свящ. 1878. Заметка сельского священника. Прибавления к Воронежским епархиальным ведомостям, 13: 502-507.

5. Всеволодов А.В. 2017. Православное приходское духовенство в 1840-1880-е гг.: материальное обеспечение, корпоративная организация, самосознание (на материалах Вологодской епархии): дис. ... канд. ист. наук. Екатеринбург, 382.

6. Ершов Б.А. 2012. Русская православная церковь в системе государственных отношений в XIX - начале XX в. (на материалах Центрально-Черноземных губерний): дис. ... докт. ист. наук. Курск, 412.

7. Журнал заседания съезда депутатов Воронежской епархии 10 января 1878 года. 1878. Вечернее заседание. Воронежские епархиальные ведомости. Официальная часть, 4: 31-33.

8. Иконников С.А. 2015. Приходское духовенство Воронежской епархии второй половины XIX - начала XX века. Социокультурная характеристика: дис. ... канд. ист. наук. Воронеж, 416.

9. Иконников С.А. 2018. Церковно-свечная операция и создание свечных заводов в епархиях Центрального Черноземья в конце XIX века: к истории вопроса. Ученые записки. Электронный научный журнал Курского государственного университета, 4 (48).

10. Леонтьева Т.Г. 2002. Вера и прогресс: православное сельское духовенство России во второй половине XIX - начале XX в. М., Новый хронограф: 253.

11. Миронов Б.Н. 2015. Жизненный уровень российского приходского православного духовенства в имперской России. Исторический журнал: научные исследования, 1: 65-80.

12. О продаже восковых свечей, выделываемых на частных заводах.1876. Воронежские епархиальные ведомости. Неофициальная часть, 18: 814-821.

13. По вопросу о церковно-свечной операции. 1878. Прибавления к Воронежским епархиальным ведомостям, 24: 924-932. 
14. Понятовский А., свящ. 1879. Результаты постановлений Воронежско-епархиальной центральной комиссии по церковно-свечной операции. Прибавления к Воронежским епархиальным ведомостям, 2: 57-68.

15. Программа действий центральной комиссии, избранной епархиальным съездом по восковой свечной операции церквей Воронежской епархии. 1878. Воронежские епархиальные ведомости. Официальная часть, 4: 38-46.

16. Сахаров И., свящ. 1878. Комиссия по свечной операции в Воронежской епархии и ее желания. Прибавления к Воронежским епархиальным ведомостям, 5: 219-225.

17. Сахаров И., свящ. 1879. По поводу статьи - результаты постановлений Воронежскоепархиальной центральной комиссии по церковно-свечной операции. Прибавления к Воронежским епархиальным ведомостям, 9: 378-390.

18. Сильченко Н., свящ. 1877. К вопросу об устройстве Епархиального свечного завода. Прибавления к Воронежским епархиальным ведомостям, 22: 518-527.

19. Склобовский Д., прот. 1880. Idem per idem. Прибавления к Воронежским епархиальным ведомостям, 9: 423-439.

20. Склобовский Д., свящ. 1877. Pia desideria: к предстоящему съезду депутатов от духовенства всей епархии (об епархиальном свечном заводе и об Эмеритальной кассе). Прибавления к Воронежским епархиальным ведомостям, 19: 368-376.

21. Склобовский Д., прот. 1878. По поводу «Заметки по Церковно-свечной операции». Прибавления к Воронежским епархиальным ведомостям, 18: 649-667.

22. Скрябин, свящ. 1879. К статье о. Склобовского по вопросу о церковно-свечной операции, помещенной в № 11 Воронежских епархиальных ведомостей. Прибавления к Воронежским епархиальным ведомостям, 14: 644-648.

23. Указатель фабрик и заводов Европейской России с Царством Польским и Великим княжеством Финляндским: Материалы для фабрично-заводской статистики. Сост. по офиц. свед. Деп. торговли и мануфактур П.А. Орлов. СПб.: Тип. братьев Пантелеевых. IX, 1881.

\section{References}

1. Aristov A., svjashh. 1878. Zametka po svechnoj operacii. Pribavlenija k Voronezhskim eparhial'nym vedomostjam [Note on candle operation. Additions to the Voronezh diocesan sheets], 12: 469-474.

2. Begovatov D.A. 2017. Gorodskoe pravoslavnoe duhovenstvo Tverskoj eparhii v pervoj polovine XIX veka: professional'naja dejatel'nost' i povsednevnaja zhizn' [The urban Orthodox clergy of the Tver diocese in the first half of the XIX century: professional activities and everyday life]. Tver', SFK-ofis, 312.

3. Belonogova Ju. I. 2017. Material'noe obespechenie cerkvej v XIX - nachale XX v. na primere hramov Volokolamskogo blagochinija Moskovskoj eparhii. Vestnik Pravoslavnogo SvjatoTihonovskogo gumanitarnogo universiteta. Ser. 2: Istorija. Istorija Russkoj Pravoslavnoj Cerkvi [Material support of churches in the 19th - early 20th centuries on the example of temples of Volokolamsk deanery of the Moscow diocese. Bulletin of the Orthodox St. Tikhon Humanitarian University. History. History of the Russian Orthodox Church], 79: 46-54.

4. Vasil'ev I., svjashh. 1878. Zametka sel'skogo svjashhennika. Pribavlenija k Voronezhskim eparhial'nym vedomostjam [Note of the village priest. Additions to the Voronezh diocesan sheets], 13: $502-507$.

5. Vsevolodov A.V. 2017. Pravoslavnoe prihodskoe duhovenstvo v 1840-1880-e gg.: material'noe obespechenie, korporativnaja organizacija, samosoznanie (na materialah Vologodskoj eparhii): dis. ... kand. ist. nauk [Orthodox parish clergy in the 1840-1880s: material support, corporate organization, self-awareness (based on materials from the Vologda diocese): dissertation of a candidate of historical sciences]. Ekaterinburg, 382.

6. Ershov B.A. 2012. Russkaja pravoslavnaja cerkov' v sisteme gosudarstvennyh otnoshenij v XIX - nachale XX v. (na materialah Central'no Chernozemnyh gubernij): dis. ... dokt. ist. nauk [Russian Orthodox Church in the system of state relations in the 19th - early 20th centuries (based on the materials of the Central Black Earth provinces) dissertation of a doctor of historical sciences]. Kursk, 412.

7. Zhurnal zasedanija s'ezda deputatov Voronezhskoj eparhii 10 janvarja 1878 goda [Journal of the meeting of the Congress of Deputies of the Voronezh Diocese on January 10, 1878]. 1878. Vechernee 
zasedanie. Voronezhskie eparhial'nye vedomosti. Oficial'naja chast' [Evening meeting. Voronezh diocesan sheets. Official part], 4: 31-33.

8. Ikonnikov S.A. 2015. Prihodskoe duhovenstvo Voronezhskoj eparhii vtoroj poloviny XIX nachala XX veka. Sociokul'turnaja harakteristika: dis. ... kand. ist. nauk [Parish clergy of the Voronezh diocese of the second half of the XIX - early XX centuries. Sociocultural characteristic: dissertation of a candidate of historical sciences]. Voronezh, 416.

9. Ikonnikov S.A. 2018. Cerkovno-svechnaja operacija i sozdanie svechnyh zavodov v eparhijah Central'nogo Chernozem'ja v konce XIX veka: $\mathrm{k}$ istorii voprosa. Uchenye zapiski. Jelektronnyj nauchnyj zhurnal Kurskogo gosudarstvennogo universiteta [Church-candle operation and the creation of candle factories in the dioceses of the Central Black Earth Region at the end of the 19th century: on the history of the issue. Scientific notes. Electronic scientific journal of Kursk State University], 4 (48).

10. Leont'eva T.G. 2002. Vera i progress: pravoslavnoe sel'skoe duhovenstvo Rossii vo vtoroj polovine XIX - nachale XX v. [Faith and progress: the Orthodox rural clergy of Russia in the second half of the XIX - early XX centuries]. M., Novyj hronograf: 253.

11. Mironov B.N. 2015. Zhiznennyj uroven' rossijskogo prihodskogo pravoslavnogo duhovenstva v imperskoj Rossii. Istoricheskij zhurnal: nauchnye issledovanija [The standard of living of the Russian parish Orthodox clergy in imperial Russia. History Journal: Research], 1: 65-80.

12. O prodazhe voskovyh svechej, vydelyvaemyh na chastnyh zavodah.1876. Voronezhskie eparhial'nye vedomosti. Neoficial'naja chast' [On the sale of wax candles produced in private factories. Voronezh diocesan sheets. Unofficial part], 18: 814-821.

13. Po voprosu o cerkovno-svechnoj operacii. 1878. Pribavlenija k Voronezhskim eparhial'nym vedomostjam [On the issue of church-candle operation. Additions to the Voronezh diocesan sheets], 24: 924-932.

14. Ponjatovskij A., svjashh. 1879. Rezul'taty postanovlenij Voronezhsko-eparhial'noj central'noj komissii po cerkovno-svechnoj operacii. Pribavlenija $\mathrm{k}$ Voronezhskim eparhial'nym vedomostjam [The results of the decisions of the Voronezh diocesan central commission for church-candle operation. Additions to the Voronezh diocesan sheets], 2: 57-68.

15. Programma dejstvij central'noj komissii, izbrannoj eparhial'nym s'ezdom po voskovoj svechnoj operacii cerkvej Voronezhskoj eparhii. 1878. Voronezhskie eparhial'nye vedomosti. Oficial'naja chast' [The program of action of the central commission elected by the diocesan congress on the wax candle operation of the churches of the Voronezh diocese. Voronezh diocesan sheets. Official part], 4: 38-46.

16. Saharov I., svjashh. 1878. Komissija po svechnoj operacii v Voronezhskoj eparhii i ee zhelanija. Pribavlenija k Voronezhskim eparhial'nym vedomostjam [The program of action of the central commission elected by the diocesan congress on the wax candle operation of the churches of the Voronezh diocese. Additions to the Voronezh diocesan sheets], 5: 219-225.

17. Saharov I., svjashh. 1879. Po povodu stat'i - rezul'taty postanovlenij Voronezhskoeparhial'noj central'noj komissii po cerkovno-svechnoj operacii. Pribavlenija k Voronezhskim eparhial'nym vedomostjam [Regarding the article - the results of the decisions of the Voronezh diocesan central commission for church-candle operation. Additions to the Voronezh diocesan sheets], 9: 378-390.

18. Sil'chenko N., svjashh. 1877. K voprosu ob ustrojstve Eparhial'nogo svechnogo zavoda. Pribavlenija k Voronezhskim eparhial'nym vedomostjam [To the question of the construction of the Diocesan Candle Plant. Additions to the Voronezh diocesan sheets], 22: 518-527.

19. Sklobovskij D., prot. 1880. Idem per idem. Pribavlenija k Voronezhskim eparhial'nym vedomostjam [Additions to the Voronezh diocesan sheets], 9: 423-439.

20. Sklobovskij D., svjashh. 1877. Pia desideria: $\mathrm{k}$ predstojashhemu s'ezdu deputatov ot duhovenstva vsej eparhii (ob eparhial'nom svechnom zavode i ob Jemerital'noj kasse). Pribavlenija k Voronezhskim eparhial'nym vedomostjam [Pia desideria: to the upcoming congress of deputies from the clergy of the entire diocese (about the diocesan candle factory and the box office). Additions to the Voronezh diocesan sheets], 19: 368-376.

21. Sklobovskij D., prot. 1878. Po povodu «Zametki po Cerkovno-svechnoj operacii». Pribavlenija $\mathrm{k}$ Voronezhskim eparhial'nym vedomostjam [Regarding «Notes on the Church-candle operation». Additions to the Voronezh diocesan sheets], 18: 649-667.

22. Skrjabin, svjashh. 1879. K stat'e o. Sklobovskogo po voprosu o cerkovno-svechnoj operacii, pomeshhennoj V № 11 Voronezhskih eparhial'nyh vedomostej. Pribavlenija $\mathrm{k}$ Voronezhskim eparhial'nym vedomostjam [To the article about. Sklobovsky on the church-candle operation, placed in No. 11 of the Voronezh diocesan sheets. Additions to the Voronezh diocesan sheets], 14: 644-648. 
23. Ukazatel' fabrik i zavodov Evropejskoj Rossii s Carstvom Pol'skim i Velikim knjazhestvom Finljandskim: Materialy dlja fabrichno-zavodskoj statistiki. Sost. po ofic. sved. Dep. torgovli i manufaktur P.A. Orlov [Index of factories in European Russia with the Kingdom of Poland and the Grand Duchy of Finland: Materials for factory statistics. Comp. by official vault Dep. trade and manufactories P.A. Orlov]. SPb.: Tip. brat'ev Panteleevyh. IX, 1881.

\section{Ссылка для цитирования статьи \\ Link for article citation}

Наумов Д.В. 2020. Дискуссия православного духовенства по поводу церковно-свечной операции и создания епархиальных свечных заводов в местной периодической печати (по материалам «Воронежских епархиальных ведомостей»). Via in tempore. История. Политология, 47 (2): 327-337. DOI 10.18413/2687-0967-2020-47-2-327-337.

Naumov D.V. 2020. The discussion of the orthodox clergy about church-candle operation and opening eparchy candle factories in local periodicals (on the materials of «Voronezh Eparhial'nye vedomosti»). Via in tempore. History and political science, 47 (2): 327-337 (in Russian). DOI 10.18413/2687-0967-2020-47-2-327-337. 